\title{
Acute toxicity, brine shrimp cytotoxicity, anthelmintic and relaxant potentials of fruits of Rubus fruticosus Agg
}

Niaz Ali $^{i^{*}{ }^{+}}$, Umer Aleem ${ }^{1 \dagger}$, Syed Wadood Ali Shah², Ismail Shah², Muhammad Junaid ${ }^{2}$, Ghayour Ahmed², Waqar $\mathrm{Ali}^{3}$ and Mehreen Ghias ${ }^{2}$

\begin{abstract}
Background: Rubus fruticosus is used in tribal medicine as anthelmintic and an antispasmodic. In the current work, we investigated the anthelmintic and antispasmodic activities of crude methanol extract of fruits of $R$. fruticosus on scientific grounds. Acute toxicity and brine shrimp cytotoxicity activity of the extract were also performed.

Methods: Acute toxicity study of crude methanol extract of $R$. fruticosus was performed on mice. In vitro Brine shrimp cytotoxicity assay was performed on shrimps of Artemia salina. In vitro Anthelmintic activity was tested against Raillietina spiralis and Ascaridia galli. Relaxant activities were tested on spontaneous rabbits' jejunal preparations. Calcium chloride curves were constructed to elucidate possible mode of action of the extract.
\end{abstract}

Results: $L D{ }_{50}$ of the extract for acute toxicity studies was $887.75 \pm 9.22 \mathrm{mg} / \mathrm{ml}$. While $C_{50}$ of the extract for Brine shrimps cytotoxicity assay was $13.28 \pm 2.47 \mu \mathrm{g} / \mathrm{ml}$. Test samples of crude methanolic extract of $R$. fruticosus (Rf.Cr) at concentration $20 \mathrm{mg} / \mathrm{ml}$ showed excellent anthelmintic activity against Raillietina spiralis. Anthelmintic activity was 1.37 times of albendazole against the Raillietina spiralis at concentration $40 \mathrm{mg} / \mathrm{ml}$. At higher concentration (40 mg/ $\mathrm{ml})$, Rf.Cr has $89.83 \%$ parasiticidal activity. The mean $\mathrm{EC}_{50}$ relaxation activity for spontaneous and $\mathrm{KCl}$-induced contractions was $7.96 \pm 0.1$ and $6.45 \pm 0.29 \mathrm{mg} / \mathrm{ml}$, respectively. EC ${ }_{50}\left(\mathrm{Log}\left[\mathrm{Ca}^{++}\right] \mathrm{M}\right)$ for control calcium chloride curves was $-1.75 \pm 0.01$ vs. EC ${ }_{50}-1.78 \pm 0.06$ in the presence of $3.0 \mathrm{mg} / \mathrm{ml}$ of Rf.Cr. Similarly, EC ${ }_{50}\left(\mathrm{Log}_{\mathrm{L}}\left[\mathrm{Ca}^{++}\right] \mathrm{M}\right)$ in the absence and presence of verapamil $(0.1 \mu \mathrm{M})$ were $-2.46 \pm 0.01$ and $-1.72 \pm 0.02$, respectively.

Conclusions: The anthelmintic and relaxant activities explained traditional uses of $R$. fruticosus on scientific grounds. Relaxant activity follows the inhibition of voltage gated channels. Although the plant extract has cytotoxic effects, yet it is evident from acute toxicity study that it is safe in concentration $100 \mathrm{mg} / \mathrm{kg}$. Further work is required to isolate pharmacologically active compounds.

Keywords: Rubus fruticosus, Anthelmintic, Ascaridia galli, Raillietina spiralis, Jejunum, Antispasmodic

\section{Background}

There are 6000 species of plants occurring in Pakistan that indicate its potential wealth. 700 species of these are used for their medicinal values, while several of them are exported [1]. Several hundred species are used in herbal remedies, in indigenous system of medicine,

\footnotetext{
* Correspondence: niazpharmacist@yahoo.com

${ }^{\dagger}$ Equal contributors

'Department of Pharmacology, Institute of Basic Medical Sciences, Khyber

Medical University, Peshawar, Khyber Pakhtunkhwa, Pakistan

Full list of author information is available at the end of the article
}

because of their medicinal importance that may be attributed to their phytochemicals [2].

$R$. fruticosus is locally known as "Karwara" [3]. It grows mostly in Northern areas of Pakistan like Malakand, Kotli, Chitral and Dir districts of Khyber Pakhtunkhwa. The plant is scrambling perennial shrub, which belongs to family Rosaceae. The family is largest dicot family of vascular plants which comprises 85 genera and 3000 species, all of which are mostly located in tropics to alpine pastures of Pakistan as evergreen or deciduous trees, shrubs and herbs [4]. 
R. fruticosus is a perennial shrub, with spiny branches, leaves tri or penta foliate; leaflets leathery, elliptic or obviate, toothed, green above, grey-woolly beneath, the terminal largest; leaf stalk with long bristles; flowers white, in dense short branched cluster and fruits are black.

It contains ascorbic acid, organic acids, tannins and volatile oils [5]. On the basis of these chemical constituents, the plant is very useful antidiarrheal and soothes inflamed mucosa. Decoction of leaves is used as tonic and gargle. Poultice of the leaves is applied to abscesses and skin ulcers [6,7].

Its ethno-medical and biological activities include antiinflammatory, antimicrobial and antioxidant. The plant is traditionally used in the treatment of wound healing, dysentery, diarrhoea, haemorrhoids, cystitis and diabetes mellitus [8]. Since the plant has potential medicinal properties as antispasmodic and anthelmintic, therefore, we conducted current work to investigate: 1) the antispasmodic activity of $R$. fruticosus in the context of abdominal pain, and 2) the anthelmintic activity of $R$. fruticosus.

\section{Methods \\ Collection, authentication and extraction of plant materials}

Mature fruits of $R$. fruticosus were collected from the nearby hilly areas of University of Malakand in the month of July, 2008. The plant was identified by plant taxonomist Professor Dr. Jehandar Shah. A voucher specimen (Rf-01-2008) was submitted to the herbarium of University of Malakand. The fruits $(0.8 \mathrm{~kg})$ were dried in shade, pulverized and macerated in hydro methanolic mixture (70\%) for 5 days. The materials were filtered off. The filtrate was combined and concentrated using rotary evaporator at controlled temperature $40-45^{\circ} \mathrm{C}$. A dark brownish extract $30 \mathrm{~g}$ was obtained.

\section{Preliminary phytochemical screenings}

The plant materials were tested for the presence of alkaloids, flavonoids, tannins, saponins, glycosides, terpenoids, sterols and carbohydrates [9-11].

\section{Solvents, chemicals, drugs and animals}

Commercial grade solvents were double distilled before its use in the experiments. Analytical grade (Merck grade) chemicals were used in the experiments. All solutions were prepared on the same day of experiments. Acetylcholine was purchased from Poole chemicals, UK. Rests of the chemicals were purchased from Merck. Rabbits (either sex) were purchased from the local market. Their average weight was in range of $1.5-2.5 \mathrm{~kg}$. They were housed in the animal house of University of Malakand and Khyber Medical University, Peshawar. Roundworms and tapeworms were obtained from the intestines of freshly slaughtered fowls. All fecal matters were removed from intestines with help of normal saline solution. The worms were collected after dissection of intestines and maintained in normal saline solution, having an average size of roundworms and tapeworms as 5-7 $\mathrm{cm}$ and 6-7 $\mathrm{cm}$, respectively. Zoologist at department of Zoology, University of Malakand identified the parasites. Experimental protocols were in compliance with "Animals Byelaws 2008 of the University of Malakand". Ethical Committee of Department of Pharmacy, University of Malakand approved the experimental protocols.

\section{Interpretation of data and statistical analysis}

Chart 7, supplied with the Power Lab, was used to interpret the data. Statistical analysis was performed at $95 \%$ confidence interval. $P$ value equal to or less than 0.05 was considered as significant. Graph Pad prism was used to calculate mean, SEM and draw the curves for $\mathrm{EC}_{50}$ shift.

\section{Acute toxicity studies}

Acute toxicity studies were performed in two phases in mice. Mice of either sex were fasted overnight. The crude methanol extract was administered intraperitoneally (i.p). In phase I, acute toxicity studies of test samples were performed in concentrations 10, 100, $1000 \mathrm{mg} / \mathrm{kg}$ (I.p) to determine lethal range. Six mice were in each test group. In the second phase, we conducted the study in concentrations 750, 1000 and $1250 \mathrm{mg} / \mathrm{kg}$ in test animals. Numbers of deaths were recorded within 24 hours. Per cent lethality was noted [12].

\section{Brine shrimp cytotoxicity}

Brine shrimps' eggs were hatched in laboratory at room temperature. 10 shrimps, $5 \mathrm{ml}$ sea water and extract in concentrations 10, 100 and $1000 \mathrm{ppm}$ were added to a vial. An incubation period of 24 hours was given at room temperature. Visual counting of dead brine shrimps (laying at bottom) was performed. Per cent cytotoxicity was determined [13].

\section{Anthelmintic activity}

Anthelmintic activity was performed against test parasites round worms (Raillietina spiralis) and tape worms (Ascaridia galli). The parasites were obtained from the intestine of infested fowls obtained from the nearby slaughter house of Chakdara. They were maintained in distilled water in petri dishes at room temperature. Tests solutions of $R$. fruticosus were prepared in concentrations of 10, 20 and $40 \mathrm{mg} / \mathrm{ml}$. Approximately $25 \mathrm{ml}$ of respective solutions along with parasites of equal size were kept in the petri dishes. Time for paralysis (anthelmintic activity) was recorded when no movement was observed except when shaken vigorously. Time for death (parasiticidal activity) was recorded when the worms did 
not show any movement by vigorous shaking nor when dipped in warm water $\left(50^{\circ} \mathrm{C}\right)$. Distilled water was used as negative control. Albendazole and piperazine citrate were used as positive controls [14-17].

Effects on spontaneous rabbits' jejunum preparations and $\mathrm{KCl}$ induced contractions

Rabbits of either sex were subjected to cervical dislocation. Their abdomens were opened and pieces of jejunums were removed. Jejunal preparations were maintained in Tyrode's solution, which was constantly aerated with carbogen gas (95\% oxygen: $5 \%$ carbon dioxide mixture). The tissues were freed from mesentery. The concentrations of constituents of Tyrode's solution were (mM): $\mathrm{KCl} 2.68, \mathrm{NaCl} 136.9, \mathrm{MgCl}_{2} 1.05, \mathrm{NaHCO}_{3}$ 11.90, $\mathrm{NaH}_{2} \mathrm{PO}_{4}$ 0.42, $\mathrm{CaCl}_{2} 1.8$ and glucose 5.55 . Preparations of about $1.3-1.5 \mathrm{~cm}$ lengths were mounted in $10 \mathrm{ml}$ tissue bath containing Tyrode's solution. Temperature was maintained as $37 \pm 1^{\circ} \mathrm{C}$. After stabilization, the test samples were tried in concentrations $0.01,0.03,0.1,0.3,1.0,3.0,5$ and $10 \mathrm{mg} / \mathrm{ml}$. Force Transducer (Model No: MLT 0210/A Pan Lab S.I.) connected with Power lab (Model No: 4/25 T) was used to record intestinal responses.

Similarly, sustained contractions were produced by 80 $\mathrm{mM}$ solution of $\mathrm{KCl}$ in the rabbits' jejunal preparations. Test samples were tested in similar concentrations to determine its possible mode of action through calcium channels [18-21].

\section{Effects on calcium chloride curves}

Since the test extract produced concentration dependent relaxation on KCL-induced contractions, hence, we constructed calcium chloride curves to search for its

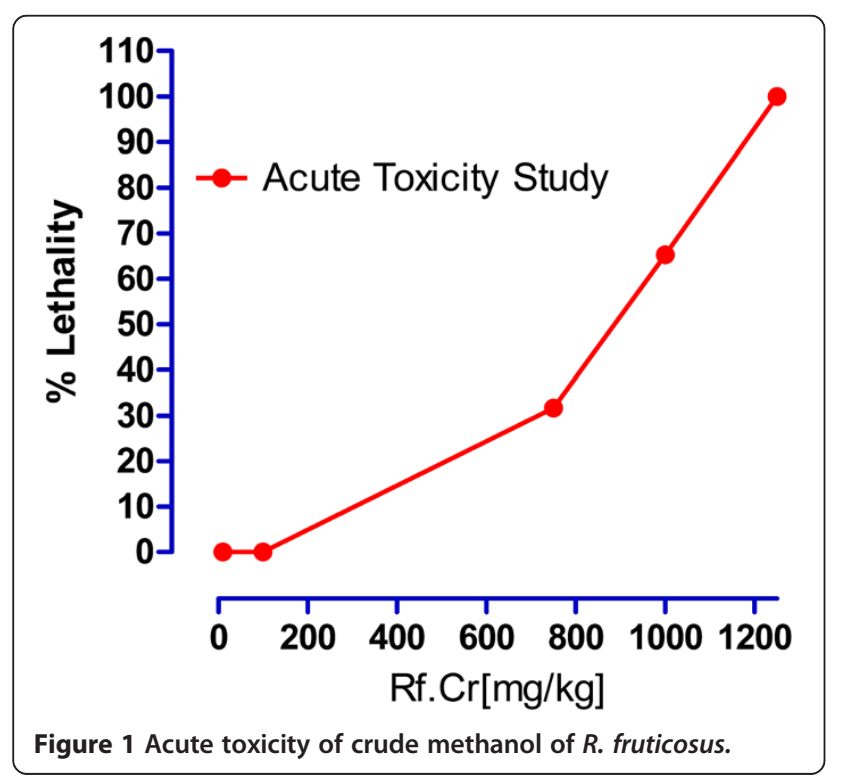

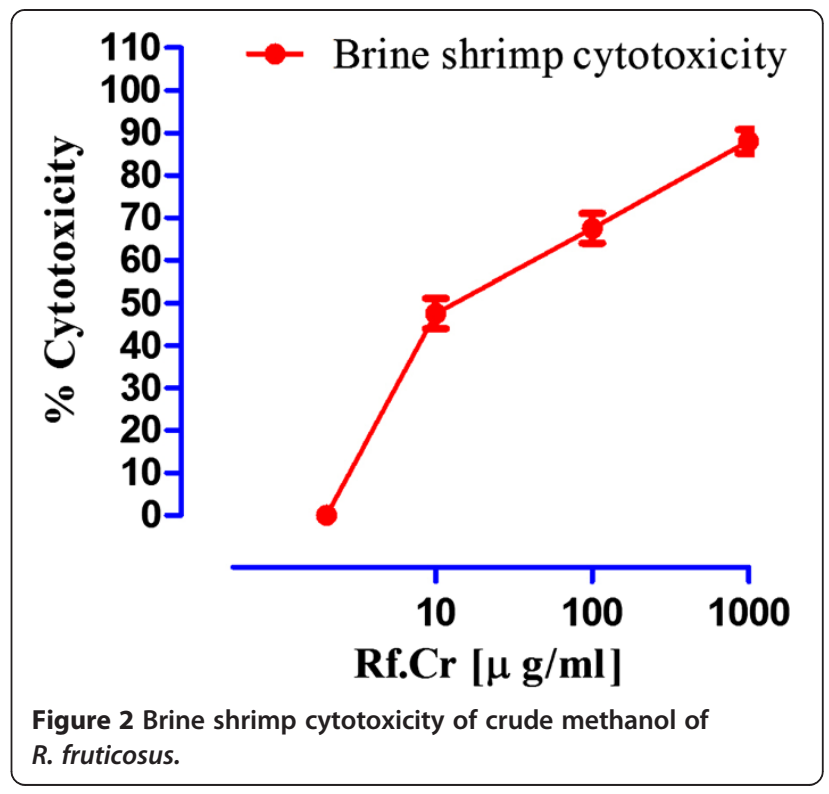

possible mode of action. Tissues were decalcified by KNormal and K-rich solution thereafter. Constituents and concentration $(\mathrm{mM})$ of K-Rich Tyrode's solution was $\mathrm{KCl} 50, \mathrm{NaCl} 91.04, \mathrm{MgCl}_{2}$ 1.05, $\mathrm{NaHCO}_{3}$ 11.90, $\mathrm{NaH}_{2}$ $\mathrm{PO}_{4}$ 0.42, glucose 5.55 and EDTA 0.1. Earlier the tissues were stabilized in normal Tyrode's solution. Control Calcium Chloride Curves (CCs) were constructed twice. Control maximum was used as standard curve for comparison. The CCs were constructed in the presence of test samples where an incubation period of one hour was given. Effects on $\mathrm{EC}_{50}$ were compared with respective control. Similarly, curves for verapamil, a standard calcium channel blocker, were constructed. Effects on $\mathrm{EC}_{50}$ were noted and compared for possible right shift [22-24].

\section{Results and discussion}

The test samples tested strongly positive for the presence of saponins. It also tested positive for the presence of flavonoids, tannins, sesquiterpenes, proteins and carbohydrates. It tested negative for terpenoids. Results of acute toxicity studies are expressed in Figure 1. The

Table 1 Anthelmintic activity of $R$. fruticosus against Raillietina spiralis and Ascaridia galli

\begin{tabular}{|c|c|c|c|c|c|}
\hline \multirow{2}{*}{$\begin{array}{l}\text { Test samples } \\
\text { and standards }\end{array}$} & \multirow{2}{*}{$\begin{array}{l}\text { Conc. } \\
(\mathrm{mg} / \mathrm{ml})\end{array}$} & \multicolumn{2}{|c|}{ Raillietina spiralis } & \multicolumn{2}{|c|}{ Ascaridia galli } \\
\hline & & $\mathbf{P}$ & D & $\mathbf{P}$ & $\mathrm{D}$ \\
\hline \multirow[t]{3}{*}{ R. fruticosus } & 10 & 101 & 161 & 100 & 159 \\
\hline & 20 & 23 & 103 & 26 & 105 \\
\hline & 40 & 16 & 59 & 19 & 59 \\
\hline Albendazole & 10 & 22 & 55 & 16 & 39 \\
\hline Piperazine citrate & 10 & 18 & 52 & 14 & 37 \\
\hline Negative control & - & - & - & - & - \\
\hline
\end{tabular}


$\mathrm{LD}_{50}$ is $887.75 \pm 9.2(n=4) \mathrm{mg} / \mathrm{kg}$. It is concluded that the extract is safe up to $100 \mathrm{mg} / \mathrm{kg}$. Results of Brine shrimp cytotoxicity are expressed in Figure 2 . Where the $\mathrm{CC}_{50}$ is $13.275 \pm 2.47 \mu \mathrm{g} / \mathrm{ml}$. It reveals that the plant extract carries cytotoxic activity and can be good source of cytotoxic compounds because of the previous literature reports for positive correlation between the brine shrimp cytotoxicity assay and human $\mathrm{KB}$ cell line (human nasopharyngeal carcinoma) [25]. Thus the current work warrants for isolation of these anticancer constituents present in the plant [26]. Results of anthelmintic activity are shown in Table 1. Time taken for paralysis and death are expressed in minutes. Test samples of crude methanolic extract of $R$. fruticosus at concentrations 20 $\mathrm{mg} / \mathrm{ml}$ showed excellent anthelmintic activity against Raillietina spiralis. Anthelmintic activity is 1.37 times

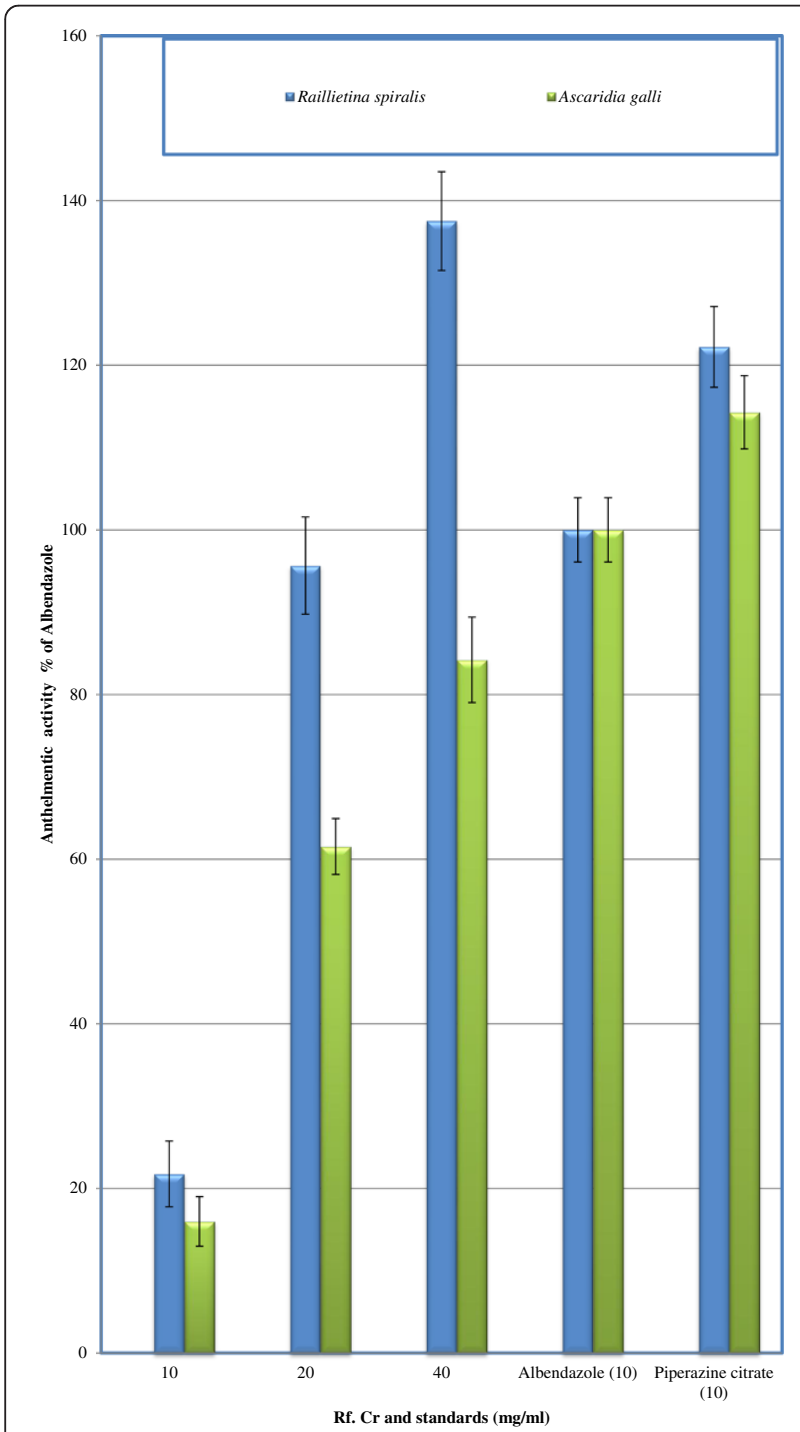

Figure 3 Anthelmintic activity of $R$. fruticosus and standard drugs. ( $n=3$, per cent expression is based on paralysis data). of albendazole against the said parasite at concentration $40 \mathrm{mg} / \mathrm{ml}$ (Figure 3). This strongly suggests its traditional use as anthelmintic. Against Ascaridia galli, anthelmintic activity is $61.5 \%$ and $84.2 \%$ at concentrations 20 and 40 $\mathrm{mg} / \mathrm{ml}$ respectively. However, parasiticidal activity, as per cent of albendazole $(10 \mathrm{mg} / \mathrm{ml})$, is expressed in Figure 4 . At higher concentration (40 mg/ml), Rf.Cr has $89.83 \%$ parasiticidal activity. It is important to note that this parasiticidal activity is percent of albendazole, a standard parasiticidal drug. Hence, the results confirm its traditional use as anthelmintic as per previous reported work. The anthelmintic activity may be attributed to the phytochemicals particularly the flavonoids, saponins, tannins and sesquiterpenes as similar types of compounds have been proven to be anthelmintic [14-17].

Relaxant activity on spontaneous rabbits' jejunal preparations and $80 \mathrm{mM} \mathrm{KCl}$-induced contractions are expressed in Figure 5. It relaxed the spontaneous contractions and showed a concentration dependent relaxing effect on jejunal preparations. Many mechanisms are sometimes involved in relaxing effect. Like relaxing effects may be either through calcium antagonistic action or through blocking of muscarinic receptors or both. In addition,

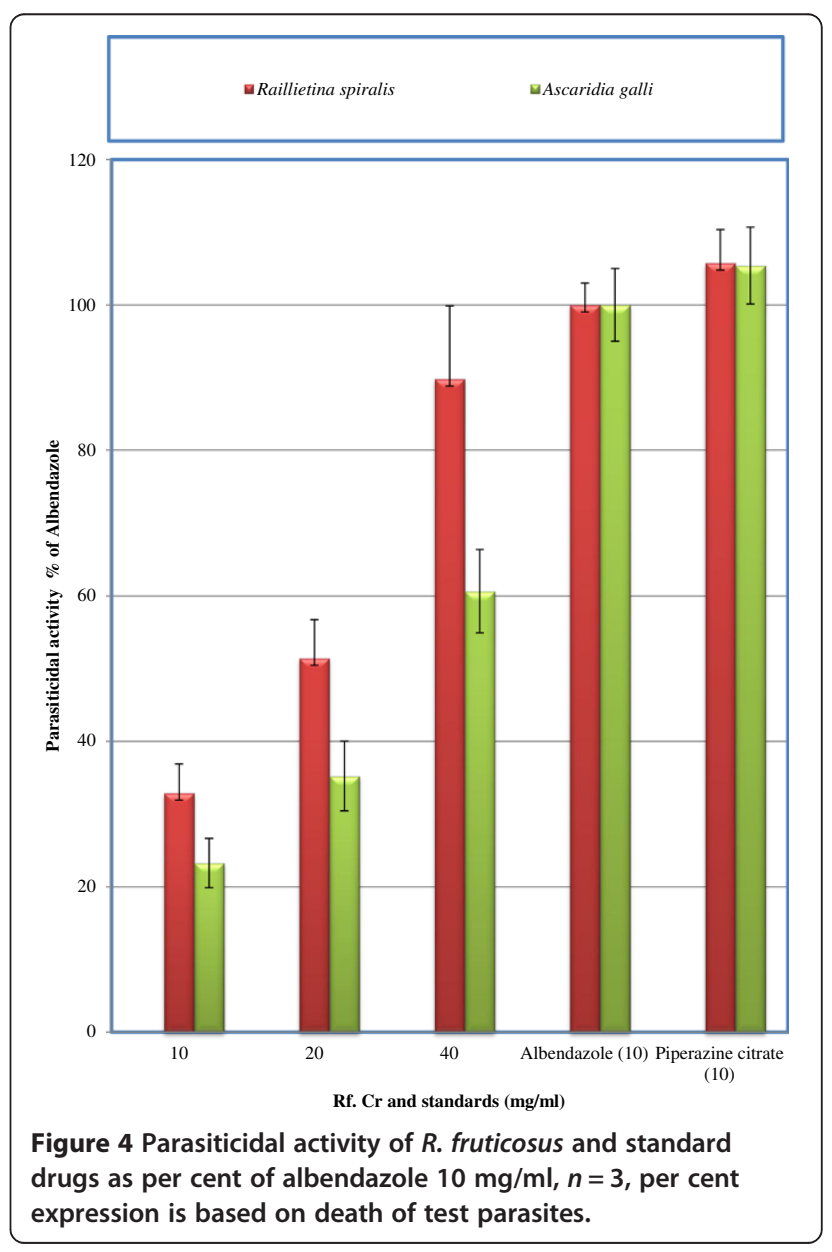




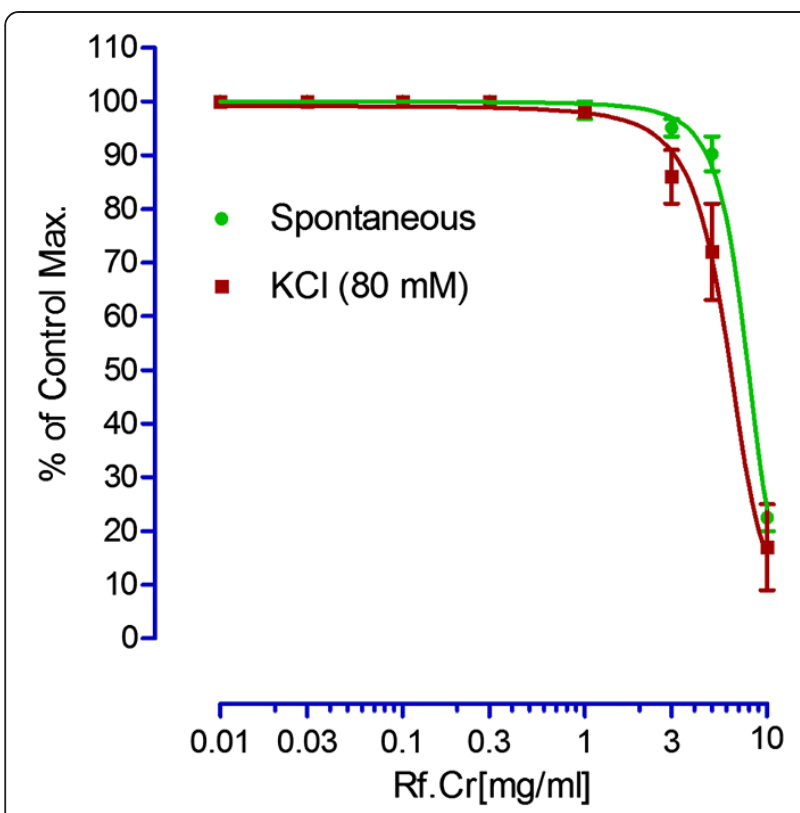

Figure 5 The effects of crude methanol extract on spontaneous and KCl-induced contractions (Values are mean \pm SEM, $n=4$, $P<0.05$ ).

there may be involvement of histaminergic receptors. Nevertheless, relaxing effects on $\mathrm{KCl}$-induced contractions provides a rapid screening for possible relaxing mechanisms that may involve voltage gated calcium channels [21-23]. Voltage gated channels play a vital role in the regulation of peristaltic movements of the intestine as it helps in periodic depolarization and repolarization of the gastrointestinal tract $[23,24]$. Since $\mathrm{KCl}$ induces contractions via calcium influx from extracellular medium to intracellular medium, hence, relaxing effects on $\mathrm{KCl}-$ induced contractions may be regarded to follow calcium channel blocking mechanism [19]. $\mathrm{EC}_{50}$ for spontaneous and $\mathrm{KCl}$ - induced contractions are $7.96 \pm 0.1$ and $6.45 \pm$ $0.29 \mathrm{mg} / \mathrm{ml}$. To confirm its possible mechanism through voltage gated channels, we constructed calcium chloride curves (CCs) in K-rich medium. CCs in the absence and presence of the test sample are expressed in Figure 6. According to Figure 6A, EC $50\left(\log \left[\mathrm{Ca}^{++}\right] \mathrm{M}\right)$ for control calcium chloride curves is $-1.75 \pm 0.01 \mathrm{vs}$. EC $50-1.78 \pm 0.06$ in presence of $3.0 \mathrm{mg} / \mathrm{ml}$. Similarly, EC ${ }_{50}\left(\log \left[\mathrm{Ca}^{++}\right] \mathrm{M}\right)$ in the absence and presence of verapamil $(0.1 \mu \mathrm{M})$ are $-2.46 \pm 0.01$ and $-1.72 \pm 0.02$, respectively (Figure $6 \mathrm{~B}$ ). Thus the right shift produced by Rf.Cr resembles the right shift of verapamil, a calcium channel blocker. Hence, we conclude that the mode of jejunal relaxation observed might be mediated by voltage gated calcium channels. The activities are attributed to the phytochemicals that are present in the extract.
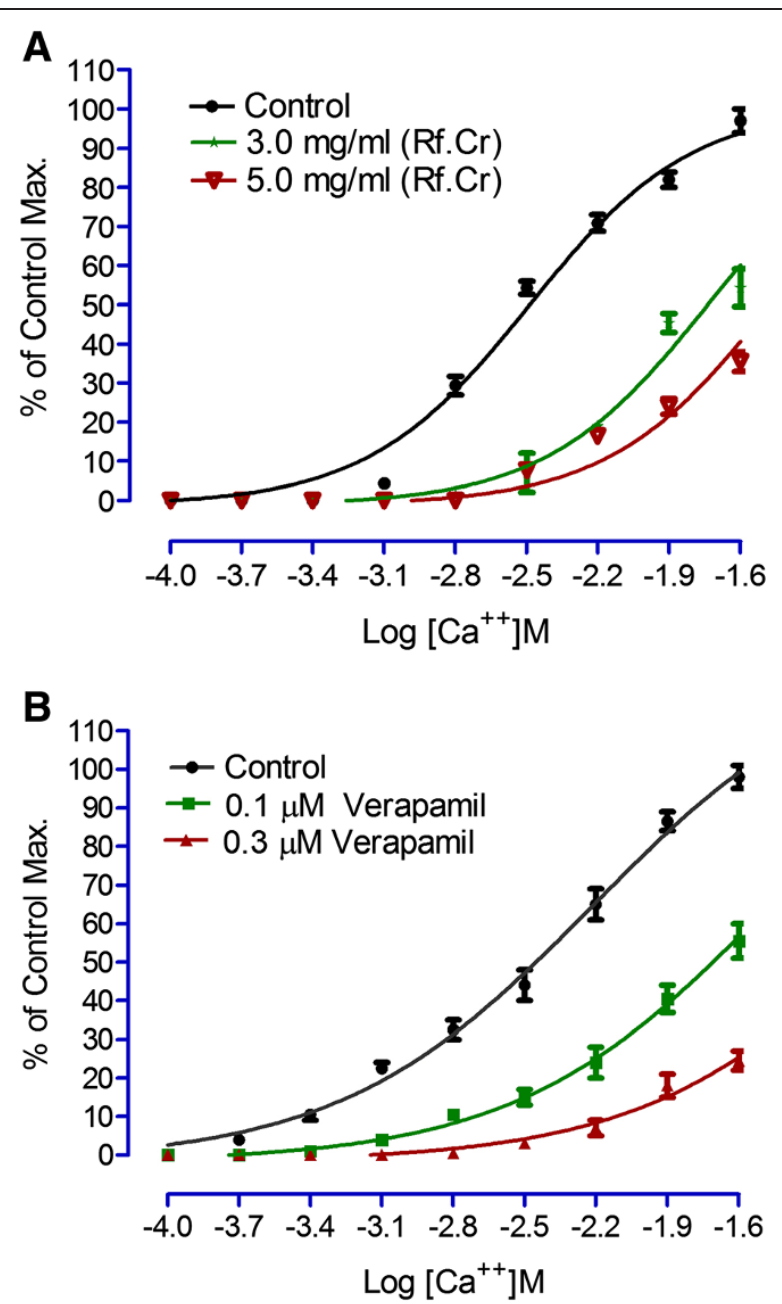

Figure 6 Constructing calcium chloride curves: A) in the absence (control) and presence of test samples. B) in the absence and presence of verapamil (Values are mean \pm SEM, $n=4$, $P<0.05)$.

\section{Conclusions}

The anthelmintic and relaxant activities explain traditional uses of $R$. fruticosus on scientific grounds. Relaxant activity follows the inhibition of voltage gated channels. Although the plant extract has cytotoxic effects, yet it is evident from acute toxicity study that it is safe at concentration $100 \mathrm{mg} / \mathrm{kg}$. Further work is required to isolate the pharmacologically active compound(s).

\section{Abbreviation}

Rf.Cr: Crude methanolic extract of Rubus fruticosus.

\section{Competing interests}

The authors declared that they have no competing interests.

\section{Authors' contributions}

NA participated in collection of CCs data, interpretation and writing the manuscript. UA M. Phil research scholar and collected the data. SWA helped in acute toxicity studies. IS helped in preparation of the extract, and literature survey. MJ helped in literature survey and phytochemistry of test samples. 
GA helped in construction of CCs. WA helped in cytotoxicity studies. MG helped in animal breeding. All authors read and approved the manuscript.

\section{Acknowledgements}

The author thanks Professor Dr. Jehandar Shah for identifying the plant. The authors want to thank the Higher Education Commission of Pakistan for providing research grant no: 20-1723/R\&D/10 for establishment of pharmacology laboratory at IBMS, KMU.

\section{Author details}

${ }^{1}$ Department of Pharmacology, Institute of Basic Medical Sciences, Khyber Medical University, Peshawar, Khyber Pakhtunkhwa, Pakistan. ${ }^{2}$ Department of Pharmacy, University of Malakand, Chakdara Dir, Khyber Pakhtunkhwa, Pakistan. ${ }^{3}$ Department of Pharmacy, Abasyn University, Peshawar, Pakistan.

Received: 8 January 2013 Accepted: 14 June 2013

Published: 18 June 2013

\section{References}

1. Shinwari ZK, Rehman UM: Pictorial Guide to Medicinal Plants of Pakistan. Kohat: KUST; 2006.

2. Zaman K: Hundred drug plants of West Pakistan. Peshawar: Medicinal plants Branch Pakistan Forest Institute; 1970.

3. Zabihullah Q, Rashid A, Akhtar N: Ethnobotanical survey in Kot Manzaray Baba valley Malakand Agency, Pakistan. Pak J PI Sci 2006, 12(Suppl 2):115-121.

4. Ali SI, Qasir M, Landrein S, Borosova R, Oborne J, Shah M, Kornik J: Roseae potentilleae. In Flora of Pakistan. 216th edition. 2009:1-138.

5. Wada L, Ou B: Antioxidant activity and phenolic content of Oregon caneberries. J Agr Food Chem 2002, 50(Suppl 12):3495-500.

6. Sher $\mathrm{H}$ : Ethnoecological evaluation of some medicinal and aromatic plants of Kot Malakand Agency. Pak Sci Res Essays 2011, 6(Suppl 10):2164-2173.

7. Riaz M, Ahmad M, Rahman N: Antimicrobial screening of fruit, leaves, root and stem of Rubus fruticosus. J Med PI Res 2011, 5(Suppl 24):5920-5924.

8. Health from nature, Remedies and natural cures. Available on link: http://health-from- nature.net/Blackberry.html [accessed date: 29-05-2012]

9. Aduragbenro DA, Yeside OO, Adeolu AA, Olanrewaju MJ, Ayotunde SA, Olumayokun AO, Janet MM: Blood pressure lowering effect of Adenanthera pavonina Seed extract on normotensive rats. Rec Nat Prod 2009, 2009(3):282-289.

10. Harborne JB: Phytochemical methods. London: Chapman and Hall; 1973:117.

11. Kokate CK, Purohit AP, Gokhale SB: Practical Pharmacognosy. 2nd edition. Pune, Mumbai: Nirali Prakashan; 1994.

12. Rehman AU, Mannan A, Inayatullah S, Akhtar MZ, Qayyum M, Mirza B: Biological evaluation of wild thyme (Tymus serpyllum). Pharm Biol 2009, 47(Suppl 8):628-633.

13. Rehman AU, Choudhary MI, Thomsen: Manual of Bioassay Techniques for Natural Product Research. Amsterdam: Harward Academic Press; 1991:82-84.

14. Ajaiyeoba EO, Onocha PA, Olarenwaju OT: In vitro anthelmintic properties of Buchholzia coriaceae and Gynandropsis gynandra extract. Pharm Biol 2001, 39(Suppl 3):217-220.

15. Vigar Z: Atlas of Medical Parasitology. 2nd edition. Singapore: P. G. Publishing House; 1984:242

16. Dash GK, Suresh P, Kar DM, Ganpaty S, Panda SB: Evaluation of evolvulus alsinoides Linn. For anthelmintic and antimicrobial activities. J Nat Rem 2002, 2(Suppl 2):182-185.

17. Shivkumar YM, Kumar VL: Anthelmintic activity of latex of Calotropis procera. Pharma Biol 2003, 41(Suppl 4):263-265.

18. Ghayur MN, Gilani AH: Pharmacological basis for the medicinal use of ginger in gastrointestinal disorders. Dig Dis Sci 2005, 50:1889-1897.

19. Shah SWA, Kamil SA, Ahmad W, Ali N: Spasmogenic, spasmolytic and antihypertensive activity of Forsskalea tenacissima. Afr J Pharma Pharmacol 2010, 4:381-385.

20. Farre AJ, Colomb M, Gutierrez B: Differential effects of various calcium antagonists. Gen Pharmacol 1991, 22:177-181.

21. Niaz A, Shah SWA: Spasmolytic Activity of Fruits of Tamarindus indica L. JY Pharma 2010, 2(Suppl 3):261-264.

22. Niaz A, Shah SWA: Antispasmodic activity of Teucrium stocksianum Bioss. Pak J Pharm Sci 2011, 24(Suppl 2):171-174.
23. Bolton TB: Mechanism of action of transmitters and other substances on smooth muscles. Physiol Rev 1979, 59:606-718.

24. Karaki H, Wiess G: Mini-review: Calcium release in smooth muscles. Life Sci 1983, 42:111-112.

25. Tawaha KA: Cytotoxicity evaluation of Jordanian wild plants using brine shrimp lethality test. J App/ Sci 2006, 8(Suppl 1):12-17.

26. Ali N, Shah SWA, Shah I, Ahmed G, Ghias M, Khan I: Cytotoxic and anthelmintic potential of crude saponins isolated from Achillea Wilhelmsii C. Koch and Teucrium stocksianum Boiss. BMC Complement Altern Med 2011, 11:106-12.

doi:10.1186/1472-6882-13-138

Cite this article as: Ali et al:: Acute toxicity, brine shrimp cytotoxicity, anthelmintic and relaxant potentials of fruits of Rubus fruticosus Agg BMC Complementary and Alternative Medicine 2013 13:138.

\section{Submit your next manuscript to BioMed Central and take full advantage of:}

- Convenient online submission

- Thorough peer review

- No space constraints or color figure charges

- Immediate publication on acceptance

- Inclusion in PubMed, CAS, Scopus and Google Scholar

- Research which is freely available for redistribution

Submit your manuscript at www.biomedcentral.com/submit 